\title{
A Mixed-Method Study of the Effect of the Demonstration Method on Students' Achievement in Financial Accounting
}

\author{
Umar Inuwa \\ Dr., Department of Vocational and technology Education, Abubakar Tafawa Balewa \\ University, Bauchi, Nigeria,inuwa_umar@oyagsb.uum.edu.my,alummari@gmail.com
}

\section{Zarifah Abdullah}

Tunku Puteri Intan Safinaz School of Accountancy, Universiti Utara Malaysia, Malaysia,zarifah@uum.edu.my

\section{Haslinda Hassan}

Tunku Puteri Intan Safinaz School of Accountancy, Universiti Utara Malaysia, Malaysia,lynn@uum.edu.my

This study examines the effect of the demonstration method on students' achievement in financial accounting in Gombe state, Nigeria. A sequential explanatory mixed-method design is used where 120 students from six randomly selected schools participated in the study. The students are equally divided into two groups, namely, experimental (i.e., demonstration method) and control group (i.e., conventional approach). Four (4) students participate in the interview. A Financial Accounting Achievement Test (FAAT) is used as an instrument for data collection. The results indicate that at the pre-test stage, there is no significant difference between the achievement of students who are assigned to the demonstration method and that of those who are assigned to the conventional method. The result suggests that the two groups are equal in terms of their achievement at the initial stage. Nonetheless, a significant difference in the financial accounting achievement of students who are exposed to the demonstration method and that of those who are exposed to the conventional method is found at the post-test stage. Specifically, the finding suggests that the demonstration approach is an effective approach to improve the achievement of financial accounting students in secondary school.

Keywords: mixed-method, demonstration method, students' achievement, financial accounting, student, teaching

Citation: Inuwa, U., Abdullah, Z., \& Hassan, H. (2018). A Mixed-Method Study of the Effect of the Demonstration Method on Students' Achievement in Financial Accounting. International Journal of Instruction, 11(4), 577-592. https://doi.org/10.12973/iji.2018.11436a 


\section{INTRODUCTION}

Financial accounting is one of the vocational subjects taught at senior secondary schools in Nigeria, aiming at equipping students with professional knowledge and skills. According to the West African Examination Council (2004), financial accounting is the most popular vocational subject offered in senior secondary schools in Nigeria. The objectives of teaching financial accounting in senior secondary schools are to enable the students to appreciate basic accounting practices, principles, and their applications in modern business activities, and to prepare students to further study in accounting and related courses at the higher institutions (National Examination Council, 2004). The financial accounting subject is very imperative to the Nigerian economy as it provides the basis for preparing future entrepreneurs, accountants, managers, and financial controllers (Francis, 2014).

Despite contribution of the subject financial accounting to the Nigerian economy, the achievement of secondary school students in this subject is far from impressive, especially in their national examination (Adeleke, Binuomote, \& Adeyinka, 2013; Mohammed, 2011). However, Ezeagba (2014) and Mohammed (2011) observed that the major factor contributing to students' failure in financial accounting is the predominant use of conventional teaching approach where teacher dominates the class and does not encourage students to participate in the learning process.

Equally, there are arguments in the existing literature (see, for example, Abimbola \& Abidoye, 2013; Dantani, 2012; Ekeyi, 2013) that conventional method is less effective in improving the achievement of students. This is due to the fact that the students are not fully involved in the learning process. Moreover, it is asserted by Akintelure in 1998 that the subject financial accounting is not learnt by memorization of accounting rules and principles, rather it requires the full participation of students in the learning process. The use of predominant teaching method (i.e., conventional approach), which involves telling, reading, and memorizing of concepts, has failed to address the issue of low students' achievement in secondary school (Kohle, 2002). Hence, there is need for appropriate instructional method for teaching financial accounting in order to address the massive and consistent failure of secondary schools students in the subject.

Furo, Abdullahi, and Badgal (2014) suggested that demonstration method could be appropriate for teaching the students of primary and secondary schools because it encourages adequate participation of students in the learning process. At present, no published study examined the effect of demonstration method on the achievement of secondary school students in financial accounting. Hence, the present study addresses this gap by examining the demonstration method effect on students' achievement in financial accounting in Gombe state, Nigeria. For this purpose, an explanatory sequential mixed-method design is used to understand the phenomenon thoroughly. With this research design, the qualitative finding explains the statistical result in detail (Creswell, 2003). Therefore, this enables the study to find and explain why the new teaching method (i.e., demonstration method) has effect on the financial accounting achievement of the secondary school students. 


\section{Problem Statement}

It has been observed by the existing studies (see, for example, Adeleke, Binuomote, \& Adeyinka, 2013; Ezeagba, 2014; Mohammed, 2011; Osuala, 2004) that the achievement of senior secondary school students in the subject financial accounting over the years, has persistently remained discouraging, especially in their national examination. The annual release of financial accounting results in the national examination has justified the claim of the government and parents as well as the problematic nature of low financial accounting achievement among secondary school students in Nigeria (Akinsolu, 2010; Alexander, Sunday, \& Kola, 2012). Previous studies (see, for example, Adeyemi, 2002; Alebiosu, 1998; Bilesanmi-Awoderu, 2006) have argued that the quality of teaching method used by the secondary school teachers is a key determinant of students' achievement. Similarly, the massive and consistent failure recorded among secondary school students in national examinations are mostly due to the teaching method employed by the teachers (Afolabi \& Akinbobola, 2009; Akinolu, 2006; Aremu \& Sokan, 2008; Ezeagba, 2014) and the persistent use of the conventional teaching approach approach where teacher dominates the class and does not encourage students to participate in the learning process (Cheung, 2007; Mohammed, 2011).

\section{Significance of the Study}

The study will be significance to the students of financial accounting in secondary school since a good method of instruction has a positive influence on the students' learning. Specifically, the outcomes of this study will also be significance to stakeholders, particularly teachers of financial accounting in secondary school, curriculum planners, and government, in terms of adopting demonstration method in teaching financial accounting to improve their students' achievement in the subject. It is also expected that the persistent and massive failure among secondary school students in the subject could be reduced.

\section{LITERATURE REVIEW}

Demonstration method is an instructional approach in which the teachers are the role players while the students observe with the aims of acting subsequently. In a demonstration approach class, the teachers explain the lesson step-by-step to the students and show them all the procedures in the lesson (Ameh, Daniel, \& Akus, 2007). Several studies have focused on the effect of demonstration instructional approach on students' achievement in various disciplines of study. For instance, Ameh and Dantani (2012), in their study examining the effect of demonstration and lecture methods on student's achievement in chemistry, found demonstration approach as effective in enhancing chemistry achievement of secondary school students. Ameh and Dantani argued that the approach allows active participation of students in the lesson. Similarly, Ogologo and Wagbara (2013) and Udo (2010) argued that due to the adequate participation of students in the learning process, the achievement of demonstration approach for students was significantly better than that of their counterparts in the conventional approach. Hemanthakumar, Sultana, and Zarzari (2013) reported a similar 
finding where the achievement of biological science students have improved significantly by using the demonstration instructional approach.

In a related study, Abdulhamid (2010) conducted a quasi-experimental study to examine the effects of demonstration and discussion approaches on secondary school students' achievement in Agricultural Science. He observed that demonstration approach developed and sustained students' learning interests, which led to their better off achievement in Agricultural Science. The finding is consistent with Ekeyi (2013) in the context of Nigeria. Ekeyi argued that due to the activity nature of the demonstration approach, the students who were exposed to this instructional approach significantly outperformed their counterparts, who were exposed to the conventional approach. Furthermore, Auwal (2013) has documented that demonstration approach enhanced the knowledge retention of Agricultural Science students. This is because in demonstration approach, the concepts are presented clearly to the learners. Adekoya and Olatoye (2011) discovered that demonstration approach is a friendly and interactive instructional approach which brought a significant change in Agricultural Science achievement of secondary school students.

On the other hand, Sola and Ojo (2007) argued that demonstration approach was less effective than the project approach. The powerful effect of project approach over the demonstration approach was relatively due to the fact that the project approach encouraged teamwork through small learning group activities, presentation, and evaluation of group work. Alike, Shoulders, Wyatt, and Johnson (2014), in the context of United States, found no significant difference in the knowledge acquisition of learners who were exposed to conventional and demonstration approach. Based on the above arguments, the following hypotheses are, therefore, formulated.

H1 There is no significant difference between the financial accounting achievement of demonstration approach of students and that of those of conventional approach students before exposing to the treatment.

$\mathrm{H} 2$ There is no significant difference between the financial accounting achievement of demonstration approach of students and that of those of conventional approach students after exposing to the treatment.

\section{METHOD}

\section{Research Design}

The study used explanatory sequential mixed-method design to examine the demonstration method effect on students' achievement in financial accounting. The design consists of two different phases (Creswell, 2003). First, the quantitative data was collected using pre-test-post-test-control group. Pre-test-post-test-control group is an experimental design, which comprises of experimental and control groups. Both groups were exposed to pre-test and post-test to determine the treatment effect (Sambo, 2005; Sekaran \& Bougie, 2013). The only difference between these groups (i.e., experimental and control groups) is that the former was exposed to treatment, while the latter was not (Sambo, 2005; Sekaran \& Bougie, 2013). Table 1 below shows the design as follows: 
Table 1

Pre-test-post-test-control group design

\begin{tabular}{lllll}
\hline G1: & $\mathrm{R}$ & $\mathrm{Y} 11$ & $\mathrm{X}$ & $\mathrm{Y} 12$ \\
$\mathrm{G} 2:$ & $\mathrm{R}$ & $\mathrm{Y} 21$ & & $\mathrm{Y} 22$ \\
\hline
\end{tabular}

G1: Experimental group (i.e., demonstration method)

G2: Control group (i.e., conventional teaching method)

R: Random assignment of subjects to the experimental and control groups.

Y11 and Y21 represent the pre-test scores of the study. The $\mathrm{X}$ in the Table 1 shows that the treatment is given to the experimental group, G1. The absence of $\mathrm{X}$ in the second row of Table 1 shows that the control group, G2 has not received any treatment. Y12 and Y22 are the post-test scores of the study.

Secondly, the qualitative data was collected through face-to-face interviews to help explain why the new teaching method tested in the first phase (i.e., quantitative aspect) has effect on financial accounting achievement of secondary school students. The use of mixed-method design allows researcher to find out the general picture of the problem, that is, demonstration effect on students' achievement in financial accounting (i.e., quantitative finding) whereas, the qualitative finding will elaborate the statistical finding obtained in the quantitative aspect (i.e., first phase) by exploring the respondents' views extensively (Creswell, 2003).

The existing studies of demonstration method (see, for example, Abdulhamid, 2010; Ekeyi, 2013; Auwal, 2013) have used quantitative method (i.e., experimental designs) in their studies. Comparatively, the present study applies both experiment and interviews to have a deeper insight into the problem under investigation

\section{Population and Sample}

The population of the present study consists of all level two (SSII) students of financial accounting in senior secondary school in Gombe state, Nigeria. This is the level where students are grouped based on their specialization area (Akanbi \& Kolawole, 2014). Therefore, the study considers only those students with interest in accounting and related courses. A cluster sampling technique was adopted to select 120 students from six (6) senior secondary schools in Gombe state. Four (4) students participated in the interview.

\section{Research Instrumentation}

In present study, Financial Accounting Achievement Test (FAAT) was use as instrument for collecting data, and it comprises 40 multiple choice questions, the questions were adapted from the past examination of West African Examination Council (WAEC). The examination is valid and reliable because it has been constructed by the experts (Osadebe, 2014), usually with try-out, analysis, and revision. The examination has also been adopted by the previous studies (see, for example, Ogologo \& Wagbara, 2013). Before conducting the actual study, the pilot study was carried out to test the reliability of the measurement instrument of the study, and it was conducted with the students that are part of the population but are not included in the sample of the study. The result 
shows a Cronbach's alpha coefficients of .85 This suggested that the instrument is reliable based on the recommendation given by Hair et al. (2010).

\section{Treatment Procedure}

Six teachers of financial accounting were randomly selected to do the experiment. The teachers have similar years of work experience and teaching qualification. A one-week orientation was received by selected teachers on how to handle the experiment. After that, the selected teachers were randomly assigned to the selected schools for the experiment. The experiment was conducted for a period of 4 weeks $\left(25^{\text {th }}\right.$ July to $19^{\text {th }}$ August 2016) and it was received only by the treatment group using demonstration teaching method as their teaching approach. The conventional teaching method (i.e., traditional teaching method) was applied in the control group.

After students were assigned to control and experimental group, the pre-test was given to assess their initial skill by their respective teachers prior to the actual treatment. After that, the experimental group students were exposed to the demonstration approach, where in the first class, the teachers explained the lesson to the students with clear examples and showed them all the steps involved in the process. Here, the teachers explained each step in the lesson clearly and accurately while the students observed. In each step of the lessons, the teachers asked the students some questions and encouraged them to ask questions on what was not clear to them. In the next class, the teachers asked some students to practice some tasks while others observed. Finally, all students were asked to perform the task (Osuala, 2004). The control group students were taught using conventional method (i.e., traditional teaching method). The activities of both groups (i.e., control and experimental) were carried out concurrently.

After 4 weeks of treatment, both control and experimental group students were given post-test to assess the effect of the treatment. All the tests (i.e., pre-test \& post-test) were submitted to the teachers (i.e., research assistants) by the students immediately after the tests. The tests were marked by the researchers.

\section{Data Analysis}

The quantitative data collected from the study was analyzed using independent sample ttest and analysis of covariance (ANCOVA). An independent samples t-test is a statistical tool used for comparing the mean score of the two different groups (Tabachnick \& Fidell, 2007). This test was performed to determine whether there is a significant difference between the financial accounting achievement of demonstration method students and that of the conventional approach students before exposing them to the treatment. Sambo (2005) argued that a usual statistical tool for the pre-test-post-testcontrol group design is ANCOVA. The ANCOVA was performed with the pre-test scores as covariates to test whether there was a significant difference between the financial accounting achievement of students who were exposed to demonstration method and that of those who were exposed to the conventional approach.

In the second phase of the analysis (qualitative aspect), the data collected from the participants (senior secondary school level two financial accounting students) through 
face-to-face interviews were thematically analyzed using qualitative research software (i.e., NVivo 10). The software was used to facilitate the process of storing, sorting, analysis, and preparing for a graphical representation of data. The use of NVivo sped up the analysis process, made it easier for the researcher to identify different relationships and enabled diagrams of emerging findings and preparation of the research reports. Clarke and Braun (2013) identified the following procedures for thematic analysis which includes; becoming familiar with the data, generating initial codes, searching for themes, reviewing themes, defining and naming themes, and producing the report. In the second phase of data analysis of this study, these procedures were followed in analysing the data collected through interviews. Then, the results of the quantitative and qualitative data were integrated in the discussion section (Ivankova, Creswell, \& Stick, 2006).

\section{FINDINGS}

The outcome of the independent-samples t-test (Table 1) indicates that before exposing students to the treatment, there was no statistically significant difference between the mean achievement score of demonstration method students $(\mathrm{M}=24.05, \mathrm{SD}=4.031)$ and conventional approach students $(\mathrm{M}=24.18, \mathrm{SD}=4.645), \mathrm{t}(118)=-.168, p=.867$. Hypothesis 1 is, therefore, supported. This finding suggested that the students of the two groups were from the same population as they were equal in terms of their achievement at the initial stage.

Table 1

Independent Samples t-test for Pre-test Scores between the two Groups Levene's Test for Equality of Variances

\begin{tabular}{llllllllc}
\hline Variable & Groups & $\mathrm{N}$ & $\mathrm{F}$ & Sig. & $\mathrm{T}$ & Mean & SD & Sig. (2tailed) \\
\hline Pre-test & Demonstration & 60 & 1.09 & .30 & -.17 & 24.05 & 4.03 & .87 \\
\hline & Control group & 60 & & & & 24.18 & 4.65 &
\end{tabular}

The outcome of the descriptive statistics (Table 2) shows that the mean achievement score of students who were exposed to the demonstration method $(\mathrm{M}=58.57, \mathrm{SD}=$ 3.456) was greater than the mean achievement score of students who were exposed to the conventional approach $(\mathrm{M}=48.13, \mathrm{SD}=4.264)$. Furthermore, the result of ANCOVA documented in Table 3 shows the significant difference between the financial accounting achievement of students who were exposed to the demonstration method and that of those who were exposed to the conventional approach $(\mathrm{F}(1,117)=612.369, p$ $=.000$, partial eta squared $=.840)$. Hypothesis 2 is, therefore, not supported. The effect size is large (Cohen, 1988).

Table 2

Descriptive Statistics

\begin{tabular}{lccc}
\multicolumn{1}{c}{ Group } & Mean & Std. Deviation & $\mathrm{N}$ \\
\hline Demonstration & 58.57 & 3.46 & 60 \\
Control group & 48.13 & 4.26 & 60 \\
\hline Total & 58.00 & 10.60 & 120 \\
\hline
\end{tabular}


Table 3

Analysis of covariance (ANCOVA) of students' achievement in demonstration method and conventional teaching approach

\begin{tabular}{lllllll}
\hline Source & $\begin{array}{l}\text { Type III Sum of } \\
\text { Squares }\end{array}$ & df & $\begin{array}{l}\text { Mean } \\
\text { Square }\end{array}$ & F & Sig. & $\begin{array}{l}\text { Partial Eta } \\
\text { Sq }\end{array}$ \\
\hline Corrected Model & $4535.62^{\mathrm{a}}$ & 2 & 2267.81 & 522.65 & .00 & .90 \\
\hline Intercept & 5214.29 & 1 & 5214.29 & 1201.70 & .00 & .91 \\
Pre-test & 1269.99 & 1 & 1269.99 & 292.685 & .00 & .71 \\
\hline Group & $\mathbf{2 6 5 7 . 1 4}$ & $\mathbf{I}$ & $\mathbf{2 6 5 7 . 1 4}$ & $\mathbf{6 1 2 . 3 7}$ & .00 & $\mathbf{. 8 4}$ \\
Error & 507.68 & 117 & 4.34 & & & \\
Total & 346590.00 & 120 & & & & \\
Corrected Total & 5043.30 & 119 & & & & \\
\hline
\end{tabular}

The second phase of data collection in this study was the interview (i.e., face-to-face interviews). The purpose of conducting the interview is to get the students' reflections on the effectiveness of demonstration method investigated using experimental procedures towards their achievement in financial accounting. This is because in explanatory sequential mixed-method design, the qualitative data elaborates the quantitative findings by exploring the participants' views (Creswell, 2003). Hence, the participants were asked to express their views on how demonstration approach improved their achievement in financial accounting using the following questions:

(a) Do you enjoy demonstration approach? Why?

(b) Do you feel that you can learn better in financial accounting when you are taught using demonstration approach? Why?

(c) In your opinion, as a financial accounting student of senior secondary school, tell me what you like in demonstration approach?

These questions were addressed by analysing the interview responses, which led to the development of the following sub-themes:

I) Enjoy demonstration method (DM)

II)Achievement in financial accounting (FA)

III) Likeness in demonstration method (DM) 


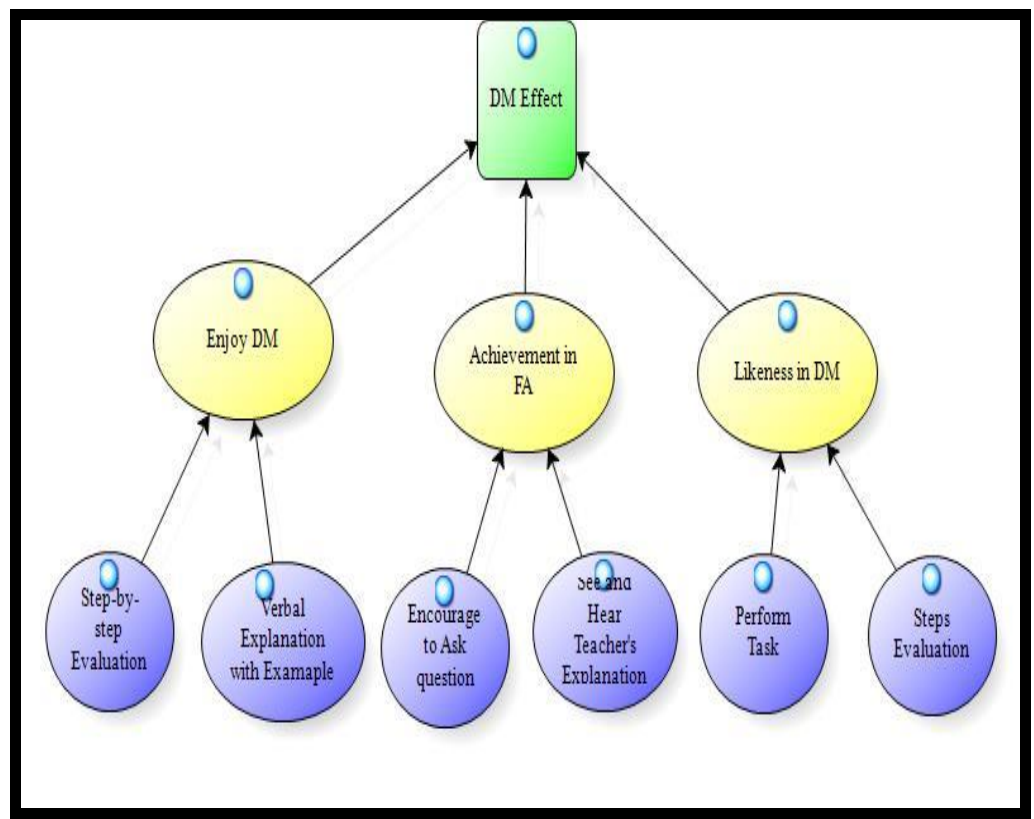

Figure 1

Model for Demonstration Method Effect

Figure 1 shows the relationship between the main theme: demonstration method effect and its sub-themes (Enjoy DM, Achievement in FA, and Likeness in DM) as generated from the participants' responses, all with their dimensions. These refers to the participants' perceptions and views on whether they enjoy learning financial accounting using demonstration method, what makes them to achieve better in financial accounting when taught using demonstration method and what they like in demonstration method.

The interview responses indicate three participants showed that they enjoyed learning financial accounting with DM because of the teachers' step-by-step explanation. One participant, on the other hand, mentioned that he enjoyed learning financial accounting with DM because of teachers' verbal explanation with examples.

Step-by-step Explanation. Three participants highlighted why they enjoyed learning financial accounting using demonstration method. They emphasized that their teacher presents the lesson step-by-step to enable them to have a good understanding of the lesson and to perform some tasks after the lesson. For instance, Participant 1 mentioned that, "Yes, I enjoyed demonstration approach because our teacher makes the lesson very clear to us by presenting it step-by-step" (Participant 1). The same view was expressed by Participant 2 where she remarked that, "Really I enjoy this teaching method because our teacher makes the lesson easy to us by presenting it step-by-step with simple examples" (Participant 2). Similarly, Participant 4 asserted that, "Yes. 
Because you would see and hear the teacher's explanation clearly, she is doing it stepby-step and she asks questions in each step" (Participant 4).

Verbal Explanation with Example. One participant from demonstration method class stressed that he enjoyed learning financial accounting using demonstration method because their teacher explained the concepts verbally with detail illustration. Based on the interview responses, the participant said that: "Yes, I enjoy demonstration method. In demonstration method's class, our teacher explained each concept verbally and demonstrate it by showing clear examples" (Participant 3).

Figure 1 also shows the perception and views of the participants regarding their achievement in financial accounting when they were exposed to demonstration method with two dimensions developed from the interview. These are: (1) see and hear the teacher's explanation, and (2) encourage to ask questions.

See and Hear Teacher Explanation. The interview responses from the participants indicated that the students achieved better in financial accounting when they were exposed to demonstration method. The approach enables them to appreciate the teacher's lesson and perform better in their academic achievement because the lesson is presented in a way that students would see and hear the step-by-step explanations of the teacher. This makes them understand the lesson and repeat what the teacher has done. For example, Participant 1 stated that: "Really I can learn better in financial accounting when taught using demonstration method. Because our teacher explained and showed us clearly how to do something and he gave us hands-on practice at the end of the lesson" (Participant 1).

The same view was expressed by Participant 2: "Yes, I can learn better using demonstration method. Because in demonstration method, I watch the teachers' demonstration step-by-step, hear all his explanation and perform some task at the end of the lesson" (Participant 2). Responding on the same issue, Participant 3 opined that, "I can do better when taught using demonstration approach. Because our teacher taught us step-by-step in a way that we can visualise and get everything clearly and repeat what she has done" (Participant 3 ).

Encourage to Ask Question. One participant from the interview expressed his view that he performed better in financial accounting when they were taught using demonstration method because their teacher encouraged to ask questions in the lesson. The following expression was stated by the participant: "Yes, I can learn better. Because our teacher teaches us and he encourages us to ask what we can see and hear at any step in the lesson and give us a task to perform after the lesson" (Participant 4).

The interview responses indicate that all the participants enjoy DM because their teacher asks them to perform a task at the end of the lesson. Participant 1 also mentioned that he likes demonstration method because of teachers' evaluation at each step of the lesson.

Perform Task. From the interview responses, participants emphasised that in demonstration method, their teachers made the lesson very clear to them, gave them tasks to perform at the end of the lesson, and showed them clearly how to do the given 
tasks. For example, Participant 1 mentioned that: "The teacher carries all the class along, he explained the lesson step-by-step. After the lesson he asked us to practice some exercises similar to what he has done" (Participant 1).

Responding to the same issue, Participant 2 stated that, "At the end of each lesson, our teacher asked us to do exercises and she guided us as necessary on how to do the exercises" (Participant 2). In a similar vein, Participant 3 expressed that, "In demonstration method, our teacher explained the lesson and showed to us clearly how to solve each problem and at the end of the lesson she asked us to do some hands-on" (Participant 3). In line with the above assertion, Participant 2 opined that, "In demonstration model, the teacher made the lesson visible and audible to us and he encouraged all the class to do the given task" (Participant 2).

Steps Evaluation. One participant also mentioned that in addition to performing a given task after the lesson, he also liked teachers' evaluation at each step of the lesson. The participant remarked that: "Our teacher carries all the class along, he explained the lesson step-by-step with examples and after each step, he asked question and he encouraged us to ask questions also after the lesson, he asked us to practice some exercises similar to what he has done" (Participant 1).

Based on the above opinions, it has been identified that demonstration instructional approach enhanced the achievement of students in financial accounting because the approach enables the students to appreciate the teacher's lesson and perform better in the subject. In this approach, the lesson is presented clearly by the teachers with detail examples, thereby enabling the students to perform their given tasks.

\section{DISCUSSION}

The finding of this study suggested that there was no significant difference between the achievement of students who were assigned to the demonstration approach and that of those who were assigned to the conventional teaching approach before their exposure to the treatment. This finding is in line with the studies of Hijazi and Al-Natour (2012), Motaei (2014), and Zakaria, Chin, and Daud (2010).

Nevertheless, after exposing the students to the treatment, a significant difference was found in the financial accounting achievement of students who were exposed to the demonstration approach and that of those who were exposed to the conventional approach. This finding suggested that the achievement of demonstration approach students is better than the achievement of the conventional approach students. This is relatively due to the fact that the teachers present the concepts step-by-step with clear and simple examples while the students can actively participate throughout the lesson period and these brought a significant change in their achievement. Therefore, massive and consistent failure of students in financial accounting in the national examination could be addressed using demonstration approach as an instructional approach. This finding is in agreement with the findings in the studies of Abdulhamid (2010), Adekoya and Olatoye (2011), Auwal (2013), and Ekeyi (2013) in Agricultural Science, Ameh and Dantani (2012), Ogologo and Wagbara (2013), and Udo (2010) in Chemistry, and Hemanthakumar, Sultana, and Zarzari (2013) in Biological Science. 
Similarly, the analysis of qualitative data revealed that the participants are of the opinions that demonstration approach enabled them to understand the financial accounting lessons because their teachers present the lessons step-by-step in a way that they could see and hear the teachers' explanations. This helped them to follow their teachers' lessons and be able to repeat what their teachers have done. In addition, their teachers made the lessons very clear to them, and at each step of the lesson, the teachers asked questions and encouraged students to ask questions about what they have seen and heard in the lesson. At the end of each lesson, students were asked to perform tasks and their teachers guide them properly on how to perform the tasks, thereby enabling their better off performance in the financial accounting.

\section{CONCLUSION}

The study focused on the effect of demonstration method on students' achievement in financial accounting in Gombe state, Nigeria. A sequential explanatory mixed-method design was adopted in the study while achievement test (i.e., FAAT) was used as the instrument. 120 students participated in the study, they were selected from 6 schools in Gombe state. The interview was conducted with 4 students.

The findings suggested that the demonstration instructional approach was effective for enhancing the financial accounting achievement of secondary school students compared to the conventional teaching approach. This is because in demonstration approach class, the teachers present the lesson step-by-step in a way that the students would see and hear the teacher's explanation. This enabled the students to actively participate throughout the lesson period because they were encouraged to ask questions at each step of the lesson, and at the end of the lesson the students were asked to practice some exercises similar to what the teacher has done during the lesson. On the other hand, in conventional approach class, students put all their focus on the teacher. Therefore, it is suggested that the secondary school's teachers of financial accounting should be encourage by government to adopt the demonstration method as an approach for teaching secondary schools students the subject financial accounting to enhance their students' achievement in the subject.

However, only level two secondary students of financial accounting are considered in the present study. Hence, the generalization of the result of this study is limited to only level two financial accounting students of secondary school. This study recommended that a similar study should be conducted in future to consider other levels of financial accounting in secondary schools. Also, future studies should consider the knowledge retention of students in financial accounting when taught using demonstration instructional approach.

\section{REFERENCES}

Abdulhamid, A. (2010). Effects of two teaching methods on secondary school students agricultural science performance in Bauchi Metropolis, Nigeria. Journal of Research in Education and Society, 1(1). 
Abimbola, I. O., \& Abidoye, F. O. (2013). Effect of qualification and experience of biology teachers on the status of ecology teaching in Kwara State. Journal of Education and Practice, 4(24), 1-8.

Adekoya, Y. M., \& Olatoye, R. A. (2011). Effect of demonstration, peer-tutoring, and lecture teaching strategies on senior secondary school students' achievement in an aspect of agricultural science. The Pacific Journal of Science and Technology, 12(1), 320-332.

Adeleke, M. S., Binuomote, M. O., \& Adeyinka, M. S. (2013). Determinants of students' academic performance in financial accounting among senior secondary school leavers in Oyo State. International Journal of Business and Management Invention, 2(5), 48-59.

Adeyemi, S. B. (2002). Relative effects of co-operative and individual learning strategies on students-declarative and procedural knowledge in map work in Osun State, Nigeria (Unpublished doctoral thesis). Department of Teacher Education, University of Ibadan, Nigeria.

Afolabi, F., \& Akinbobola, A. O. (2009). Constructivist problem based learning technique and the academic achievement of physics student with low ability level in Nigerian secondary schools. Eurasian Journal Physics \& Chemistry Education, 1, 4551.

Akanbi, A. A., \& Kolawole, C. B. (2014) Effects of guided-discovery and self-learning strategies on senior secondary school students' achievement in biology. Journal of Education and Leadership Development, 6(1), 19-42.

Akinolu, B. M. A. (2006). Causes of mass failure in senior secondary school chemistry in Ijebu East Local Government Area of Ogun State. Oro Science Educational Journal, 4, 19-24.

Akinsolu, A. O. (2010). Teachers and Students' Academic Performance in Nigerian Secondary Schools: Implications for Planning. Florida Journal of Educational Administration \& Policy, 3(2), 86-103.

Akintelure, S. L. (1998): Comprehensive book-keeping and accounts for senior secondary school: Sure-bet for WAEC. Lagos: Johnson publishing Ltd.

Alebiosu, K. A. (1998). Effects of two co-operative learning models on senior secondary school students learning outcomes in chemistry (Unpublished doctoral thesis). University of Ibadan, Nigeria.

Alexander, O., G., Sunday, O., S., \& Kola A. J. (2012). Cause of poor performance in West African School Certification Examination in Nigeria. Scholars Journal of Arts, Humanities and Social Sciences 2(5), 670-676.

Ameh, I-Ei, Daniel, B. P., \& Akus, Y. (2007). Research and Methods in the Social Sciences. Ankpa: Rowis press. 
Ameh, P. O., \& Dantani Y. S. (2012). Effect of lecture and demonstration methods on the achievement of students in chemistry in Nassarawa Local Government Area of Kano State. International Journal of Modern Social Sciences, 1(1), 29-37.

Aremu, A. O., \& Sokan, B. O. (2008). A multi-causal evaluation of academic performance of Nigerian learners: Issues and implications for national development. Department of Guidance and Counselling, University of Ibadan.

Auwal, A. (2013). Effects of teaching method on retention of agricultural science knowledge in senior secondary schools of Bauchi Local Government Area, Nigeria. International Journal of Science and Technology Education Research, 4(4), 63-69.

Bilesanmi-Awoderu, J. B. (2006). Effect of computer-assisted instruction and simulation/ games on the academic achievement secondary school students in biology. Sokoto Educational Review, 8, 49-60.

Cheung, D. (2009). Students' attitudes toward chemistry lessons: The interaction effect between grade level and gender. Research in Science Education, 39(1), 75-91.

Clarke, V., \& Braun, V. (2013). Teaching thematic analysis: Overcoming challenges and developing strategies for effective learning. The Psychologist, 26 (2), 34-37.

Creswell, J. W. (2003). Research design: Qualitative, quantitative, and mixed methods approaches (2nd ed.). Thousand Oaks, CA: Sage Publications

Ekeyi, D. N. (2013). Effect of demonstration method of teaching on students achievement in agricultural science. World Journal of Education, 3(6), 1-7.

Ezeagba, C. (2014). The problems in the teaching and learning of accounting as a vocational subject in Nigeria secondary schools. AFRREV STECH: An International Journal of Science and Technology, 3(2), 208-226.

Francis, N. P. (2014). Climate change and implication for senior secondary school financial accounting curriculum development in Nigeria. Journal of Education and Practice, 5(26), 153-157.

Furo, R. J., Abdullahi, Y., \& Badgal, B. E. (2014). Effects of demonstration and lecture methods of teaching apiculture on achievement of agricultural students in Adamawa State University, Nigeria. Scientific Papers Series-Management, Economic Engineering in Agriculture and Rural Development, 14(2), 173-178.

Hair, J. F., Hult, G. T. M., Ringle, C., \& Sarstedt, M. (2010). A primer on partial least squares structural equation modelling (PLS-SEM). Thousand Oaks, CA: Sage Publications, Incorporated.

Hemanthakumar, A. G., Sultana, Z., \& Zarzari, H. (2013). A study of demonstration method as an activity based method of teaching biological science. International Indexed \& Refereed Research Journal, 4, 47-48. 
Hijazi, D., \& Al-Natour, A. (2012). Teachers' attitudes towards using cooperative learning for teaching English skills. Interdisciplinary Journal of Contemporary Research in Business, 3(12), 443.

Ivankova, N. V., Creswell, J. W., \& Stick, S. L. (2006). Using mixed-methods sequential explanatory design: From theory to practice. Field methods, 18(1), 3-20.

Kohle, K. (2002). Freedom, peace and personality. Education: A biannual collection of recent German contribution to the educational research, 24.

Mohammed, I. A. (2011). The challenges of teaching financial accounting in Nigerian secondary schools: A case study of Gombe state. Available at SSRN 1854322.

Motaei, B. (2014). On the effect of cooperative learning on general English achievement of Kermanshah Islamic Azad University Students. Procedia-Social and Behavioral Sciences, 98, 1249-1254.

National Examination Council (2004). Regulations and syllabus for senior secondary school certificate examination. Minna: NECO.

Ogologo, G., \& Wagbara, S. (2013). Effect of demonstration, strategy on senior secondary school students' achievement in separation techniques in chemistry inbio/Akpor local government area, Rivers State. Journal Vocational Education \& Technology, 10(2) 15-29.

Osadebe, P. U. (2014). Construction of Economics achievement test for assessment of students. World Journal of Education, 4(2), 58.

Sambo, A. A. (2005). Research methods in education. Ibadan: Evans Brothers Nigeria Ltd.

Sekaran, U., \& Bougie, R. (2013). Research methodology for business: A skill building approach. Chichester: John Wiley \& Son Ltd.

Shoulders, C. W., Wyatt, J. D., \& Johnson, D. M. (2014). Demonstrations and lectures about solar energy in Arkansas: The importance of experiential learning. Energy Research \& Social Science, 4, 100-105.

Sola, A. O., \& Ojo, O. E. (2007). Effects of project, inquiry and lecture-demonstration teaching methods on senior secondary students' achievement in separation of mixtures practical test. Educational Research and Reviews, 2(6), 124.

Tabachnick, B. G., \& Fidell, L. S. (2007). Using multivariate statistics (5th ed.). Boston: Pearson Education Inc.

Udo, M. E. (2010). Effect of guided-discovery, student-centered demonstration and the expository instructional strategies on students' achievement in chemistry. African Research Review, 4(4), 389-398.

Uzoagulu, A. E. (2011). Practical guide in writing research project reports in tertiary institutions. Enugu: Jacob's classical Publisher Ltd. 
West African Examination Council (2004). Chief examiners report: May/ June West African senior school certificate examination. Lagos: WAEC.

Zakaria, E., Chin, L. C., \& Daud, M. Y. (2010). The effects of cooperative learning on students' mathematics achievement and attitude towards mathematics. Journal of Social Sciences, 6(2), 272-275. 